rozhovor 



\section{Mým uším zní čeština překrásně}

S Raijou Hauckovou, bohemistkou, překladatelkou a lektorkou češtiny a ruštiny na starobylé univerzitě v německém Greifswaldu se znám již více než čtvrt století. Ve dnech, kdy pracovala na překladu několika nejnovějších českých knih pro prezentaci na knižním veletrhu v Lipsku v březnu 2019, jsme se sešli, abychom pohovořili o její rozmanité a inspirativní práci zprostředkovatelky české kultury. Ačkoliv to není zcela profesionální, ponechal jsem v rozhovoru vzájemné tykání. Umožňuje mi zachovat přátelský tón rozpravy.

Raijo, proč se věnuješ bohemistice? Mohou za to Tví učitelé, prátelé, oblíbení spisovatelé, Tví studenti, že bezmála třicet let jsi lektorkou češtiny? Nebo za to může salko, burčák a oplatky?

Jednoduchá odpověd'. Vyrůstala jsem na severu Německa. Češi hojně jezdili k Baltu, kde se rodiče nějakou náhodou seznámili s jednou rodinou z Haviŕrova. Když jsme potom jeli na návštěvu do Československa, to mi možná bylo tak dvanáct let, byla to asi nejlepší dovolená mého dětství. Vždycky jsem byla strašně moc zvědavá - a tady to bylo jiné, jiná řeč, jiné jídlo. A je pravda, že k tomu patří i salko, vzpomínám si i na chlebíčky, ty v dětských očích vypadaly zajímavěji než u nás.

\section{Že by se tehdy uchytilo první semínko?}

Tehdy jsem si ani neuvědomovala, že jsme se mohli domluvit jenom proto, že ti známí mluvili německy. Ale to jsem později napravila. Jako druhý slovanský jazyk jsem si během studia slavistiky k ruštině vybrala češtinu. A polštinu jsem začala studovat až po absolutoriu, tedy až v Greifswaldu, při psaní disertace o ruské syntaxi. A po převratu se vyskytla možnost znovu se věnovat češtině. Čeština je krásný jazyk. Je pravda, že jsem nevěděla, jaká je bohatá, když jsem si ji vybírala. Vždy mě hodně zajímal historický vývoj jazyka. Během studia byla staroslověnština můj možná nejoblíbenější předmět, takže výběr češtiny i v tomto ohledu byla štastná náhoda, protože historický vývoj češtiny je rovněž velice zajímavý. A potom byla další náhoda, že jsem se pro další vzdělání dostala do Brna, kde jsem potkala ty nejzajímavější, nejangažovanější kantory. V Brně 
jsem se teprve doopravdy zamilovala do jazyka, země, přesněji do Moravy, jejích lidí, písniček a kultury vůbec.

Čteš anglicky, rusky, polsky, ukrajinsky, slovensky... Co Ti dalo poznání české literatury, českého jazyka?

Ráda čtu, tak jsem ráda, že nemusím číst jenom v jednom jazyce. Jak působí na jiné lidi, nevím, ale mým uším zní čeština překrásně. Znalost českého jazyka mi otevírá možnost porovnávat příbuzné slovanské jazyky. Čeština je jazyk, ve kterém přece jen cítím, že jsme - Češi a Němci - po staletí žili vedle sebe. Potýkáme se se stejnými problémy, dělíme se vlastně o stejnou zemi, kontinent, přírodu, historii... Jsou tu samozřejmě i rozdíly, které vyplývají z toho, že se potýkáme s odlišnými problémy, dělíme se o trochu odlišný kus země, přírody, historie, sousedů... V tomto smyslu je i dnešní česká literární produkce možným zdrojem obohacení. Jako pedagog mohu také českou literaturu téměř od počátku zařazovat do výuky jako autentické texty.

Čím je specifická výuka češtiny na univerzitě vzdálené od dnešního českého státu pět set kilometrů?

No to je právě ten problém. Je jasné, že v Bavorsku by se studium bohemistiky mělo bez problémů udržet, ale v evropském měřítku se asi bude víc koncentrovat. Na druhou stranu 500 kilometrů nepovažuji za tak velkou vzdálenost, aby se tam student nemohl jednou vydat sám na výlet nebo na studium.

Student v Greifswaldu nebo v Bochumi sice své čerstvě nabyté znalosti nemůže hned vyzkoušet výletem za nedaleké české hranice. - Má to ale i své výhody. Na univerzitě, jako je Greifswald, se třeba se začátečníky mohu soustředit na spisovnou češtinu, aniž mi řeknou, že na vlastní uši slyšeli úplně jiné tvary. Nebo mohu se studenty jenom číst, pokud projevují zájem spíš o literaturu. Se studenty, kteří již znají jiný slovanský jazyk, se můžeme soustředit na porozumění českému textu na základě již existujících znalostí. Obecně řečeno, zájem o češtinu nemusí být ryze praktický, když jsme takový kus vzdálení od Čech.

Jakou šanci dáváš češtině jako cizímu jazyku v soustavě slavistických studií v zahraničí a proč?

Dnes se studuje víc „aplikovaně“, mám dojem, že studovat „klasicky“ filologie 
brzy nebude možné, ale třeba se mýlím. Takže bude se studovat, ale možná spíš v rámci nějakých (středo)evropských studií. Čeština je samozřejmě „menši“ jazyk s relativně malým počtem mluvčích, tedy je vlastně i logické, že ji studuje méně lidí než například polštinu. Ale pevně věřím, že si své postavení udrží, protože studovat jazyky svých sousedů je důležité. Dnešní člověk podle mého prostě musí chtít vědět, o čem se za kopcem mluví.

Učíš na univerzitě i mimo ni také překládání. Dá se prekládání naučit? Máš na to nějaké své specifické metody?

Nejraději pracuji se smíšenými skupinami, s jazykově smíšenými skupinami. Studenti překládají v tandemu, spolupracují navzájem. Já sleduji správnost jejich uvažování a případně opravuji chyby, které vznikají neporozuměním nebo interferencí. Obecně se překládání naučit samozřejmě dá, ale když máš na mysli literární překlad, chce to asi umělecké sklony. Nedávno jsem našla poznámku Juriho Elperina, úspěšného překladatele, že by překladatel literárních děl měl mít schopnost sám psát. Ale to lze, jak tvrdíš sám, také studenty naučit.

Na jakých typech textu překládání vyučuješ?

Pracujeme především s literárními texty. Ty považuji každopádně za nejlepší, protože nejlépe zprostředkují emoce. Ani publicistické texty, pokud je v překladatelských seminářích používám, nezprostředkují tak dokonale zkušenost s jazykem, kterým jednáme. Naše promluvy jsou doplněny o gesta, pohyby, obsahují pocity, emoce. (Když se např́iklad učíme slovesa pohybu, nutím studenty, aby to současně předváděli a pobíhali po třídě.) Proto pokud to atmosféra a schopnosti skupiny jenom trochu umožňují, překládáme texty dramatické nebo takové, které divadelní ztvárnění umožňují. Studenti pak na závěr semestru předvádějí své texty ve vlastním scénickém provedení, ve vlastní dramatizaci. Je nesmírně důležité, aby si sami studenti také mohli s těmi texty hrát a aby je potom mohli i hrát.

S jakými českými autory jste takto $v$ seminářích pracovali?

Květa Legátová, Jan Faktor, Jiří Kratochvil, Lidka Kábrtová. Občas jsme měli možnost pozvat české autory na veřejná čtení do Literaturhausu Köppenhaus v Greifswaldu nebo na kolokvia Junge Literatur in Europa nadace Hans-Werner-Richter-Stiftung. Např. Kateřina Tučková tady byla, Petr Čichoň, na setkání 
lektorů a studentů češtiny přijeli Radka Denemarková a Martin Ryšavý. Ale nejraději vzpomínám na práci s texty Ivana Wernische.

\section{Proč?}

Wernischovy texty jsou krásné. Jazykově vynalézavé. Občas jsou jaksi zvláštní. Tedy působí na čtenáře divně, protože jsou neobvyklé. Jeho texty nám umožnily pracovat na překladu i se začátečníky, a přitom nešlo o nic triviálního. Veřejná prezentace jednoho Wernischova textu, kde hlavní roli hrál hořící buben a párky s hořčicí, přešla plynule v kolektivní performance. A ti studenti, kteří to hráli, na takovou výuku nezapomenou.

Jaký prostor má v práci prekladatele tvořivost?

Vím, že to asi není názor, který se běžně vyučuje, ale myslím si, že každý překlad je tvořivý. Vycházím z toho, že už když vidím nějaký text, ve svém nebo v cizím jazyce, nebo dokonce v obrazech, tak si ho vždycky v mozku „překládám“. V mozku provádím potřebnou operaci, abych si tuto skutečnost dala do svých pojmů, abych textu porozuměla. Podle mě už každé vnímání je tvůrčí aktivita. Takové tvưrčí porozumění je základem interpretace, což je základ překladatelovy tvůrčí práce. - Ale na druhou stranu to samozřejmě tak jednoduché není, protože literární jazyk předlohy může být dosti komplikovaný. Ale když je jasné, co chtěl autor říci, jaký je autorův stylistický záměr, jaký je jeho estetický systém, když text neobsahuje chyby, tak není nutno výchozí text dovysvětlovat, zbavovat defektů, parafrázovat. (Samozřejmě nemluvím o metaforách, idiomatice apod., kde má tvưrčí „parafrázování“ svůj systém.)

Přitom já můžu přeložit výchozí text jenom tak, jak mu rozumím já. Jinak může číst muž, jinak žena, jinak dospělý a jinak mladý člověk, jinak Američan a jinak Středoevropan. Roli hraje i čtenářská zkušenost. Jinak čte člověk ze Západu, jinak v Brně. Takže každý překladatel čte, interpretuje a překládá knihu jinak. Stejná kniha může být jinak tvořivě, a zároveň kvalitně přeložena.

Co má dělat překladatel, aby byl jeho prèklad dobrý?

Překladatel by se měl pokoušet předat opravdu to, co chtěl autor říct. A zároveň by měl myslet na své publikum, aby tomu publikum mohlo porozumět. Nesouhlasím úplně s tvrzením, že překlad má plnit tytéž funkce jako originál, 
že text má být ekvivalentní. To si myslím ne vždy půjde. Mezi češtinou a němčinou nejsou zase takové rozdíly, ani mezi jazyky ani mezi způsobem života, aby nešlo sdělení porozumět. Všechno, co je v Evropě, tak je si asi dost blízké. Ale když překládáme ze zcela odlišné nebo do odlišné kultury, stěží asi může literární překlad plnit tytéž funkce. Kdybych např́klad překládala do kultury, kde děti musí bezpodmínečně poslouchat své rodiče nebo jsou víceméně majetkem svých rodičů, tak tam překládat dětskou literaturu, která třeba vyzývá k nějakému vzdoru vůči rodičům, bude obtížné. Ovšem překladatel si musí umět poradit. Dobrý překlad by měl především zaujmout čtenáře. To ale nezávisí jenom na práci překladatele. To je taky práce nakladatele, redaktora, který lektoruje rukopis překladu, reklamy, toho, jak se kniha prezentuje v přijímající kultuře.

A také tu stále větší roli hraje čas. To je také asi největší rozdíl mezi teorií a praxí. Dnes i tradiční čtení probíhá mnohem rychleji a povrchněji. Sami autoři potvrzují, že pokud jejich dílo nezíská do půl roku nějakou literární cenu, tak definitivně mizí z knihkupeckých pultů. Literatura je zboží, čtenář musí titul stihnout začerstva. Jde to asi stejně rychle jako v módě. Ale i kdyby přeložená kniha cenu získala, střídá se všechno tak rychle - jako ostatně vše v jednadvacátém století -, že i oceněná kniha je záhy odsunuta stranou, protože ji vystřídá nová oceněná kniha.

Má tedy vůbec smysl věnovat se tak detailně kvalitnímu překládání?

No když člověka to překládání baví, tak se tomu může věnovat i detailně.

Nebylo by lepší nechat knihy prekládat stroje?

Je zajímavé pozorovat pokusy v oblasti umělé inteligence, ale zatím to ještě ideálně nefunguje.

Pro Tebe ovšem je překládání jednou z mnoha aktivit pedagožky na univerzitě.

Ano, a někteří mí osvícení šéfové mne v tom podporují a berou mé překládání jako nedílnou součást mé odborné profilace. Tedy jako součást zprostředkovatelské role na poli kulturní výměny. 
Kolik jazyků umíš? Pojd’me to vyjmenovat: česky, rusky, polsky, ukrajinsky, anglicky, francouzsky, slovensky, staroslověnsky - ...

Pardon, na to je jednoduchá odpověd’: já umím německy. A tu němčinu umím jakž takž. - Nerada říkám, že něco umím, protože německy umí Goethe. A česky umí Skácel.

Raijo, děkuji Ti za rozhovor.

Dr. phil. Raija Hauck, slavistka, přkladatelka, lektorka čestiny a ruštiny na Universität Greifswald. Vede a moderuje prekladatelské workshopy, autorská čtení a bilaterální kulturní projekty doma i v zahraničí. Publikuje odborné translatologické a lingvistické studie, preklady próz, lyriky, esejů, dramatických a vědeckých textů - napr̆. Radek Fridrich, Radka Denemarková, Jiři Kratochvil, Tereza Boučková, Květa Legátová, Alexandra Berková, Milan Ohnisko, Martin Machovec, Marek Toman, Lidmila Kábrtová, Zbyněk Fišer, Natalja Tolstaja.

Zbyněk Fišer 